\title{
JobStart
}

\section{Part 5 \\ Writing the Cover Letter}

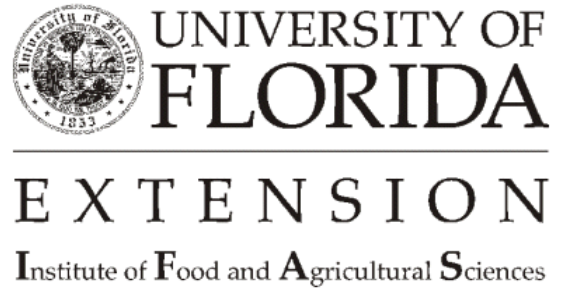




\section{Why a Cover Letter?}

Imagine just for a minute that you heard about this great job opening from a friend who works for a local company. You have the perfect resume already completed and are ready to send it to the person who your friend indicates will be doing the hiring for the opening. Are you going to send your resume to this person without any communication what so ever? What would the person doing the hiring think if he or she received a resume with no other correspondence to accompany it? Remember that a resume is a tool used to describe your education, experience, and special skills. It is not a method of communication between you and a representative of a company that is in a position to hire you.

To solve this problem the cover letter is used. The cover letter is a one page letter that accompanies a resume when it is sent to an employer. It does not have to be a long or wordy letter, but one that serves to introduce who you are and why you have sent your resume.

The cover letter also serves many other needs as well. A good cover letter will target the resume to a particular person within the company and make it more personal. It will let you highlight specific skills that could be important to the reader. It also allows you to state to the reader why you chose this particular company and how you can benefit them.

A cover letter should make the employer interested in you. It is actually a method of selling your skills and experiences. Unless the cover letter generates interest, you will not get an interview. Further, the prospective employer will probably not bother to look at your resume.

The best reason to send a cover letter with your resume is that most employers expect to see one with a resume. Resumes are impersonal. An employer could think that you just sent him or her a resume at random and are sending resumes to many companies at one time. This is not the impression you want an employer to get when they receive your resume. You want the employer to get a good feeling about you from the very first. You want him or her to know that you are interested in their company and that you know who they are. You want them to know that you are a qualified candidate who can benefit the company.

The last reason to write a cover letter is to let the employer know that you plan on making contact with them. Your letter will state that you will either contact them by phone or in person and it will tell them when to expect this contact. It notifies the employer that you expect them to do more than file your resume away in a cabinet to be forgotten. In this publication you will learn you the basics of writing a cover letter that is effective and professional.

\section{What's in a Cover Letter?}

There are many ways to write a cover letter, but all good cover letters include the same basic information. What we will do here is present to you a simple format that you can use to plug in this basic information no matter what the situation. 


\section{Your Name, Address and Date}

This information is usually placed at the top-center or top-right of the cover letter. Be sure to give your complete address even though you are writing to someone in the same city. The date goes underneath your address. Your also name goes at the bottom of the letter after the complementary close. It is typed and placed about 4 single spaces under your closing.

\section{Name, Title and Address of Person To Whom You Are Writing}

This information is typed beginning at the left margin with each line of the address beginning on a new line. It is best to always have a name of the person that will read your cover letter. You can phone the company to get the name and title of this person, if you do not have it already. Sometimes you will be unable to get this name. In this case you should address the cover letter to the company or the department you want to work for within the company.

\section{Purpose of Your Letter}

This first paragraph of the cover letter goes directly underneath the salutation. It is the section where you will state the reason why you have sent your resume and cover letter. You will indicate the position for which you are interested, or if there is no opening you can express your interest in the company. The first paragraph is very important because it is here that you will stimulate interest in your resume or that you will lose their interest completely.

\section{Your Qualifications}

In this second paragraph you will highlight your best qualifications for the position or company and remark on their relevance to the company. Here, unlike the resume, you can state your abilities and personal qualities that make you an excellent choice for hire. This is the "selling" paragraph that highlights your unique skills and experiences that make you perfect for the job. State more than what you have included on your resume. Elaborate on some of your experiences that would be of interest to the employer.

\section{A Word of Thanks}

A simple line showing your appreciation is a good idea.

When you have finished your cover letter, ask yourself if it answers the following questions: 
1. Does it persuade the reader to take a close look at your resume? Your cover letter should heighten the reader's interest in your qualifications. It is a sales instrument that promotes your personal and professional qualities.

2. Did you take time to personalize your cover letter by getting the name and address of the most appropriate person to whom to send your resume? A cover letter addressed to an individual is more likely to generate interest that will result in an interview than one addressed to the personnel department.

3. Are you willing to follow up with a phone call within one week after you sent the letter and resume? Don't assume that the reader will call you. Break the ice by calling him or her within one week. People in work settings lead busy lives. Be prepared to have to make the initial contact after you send your resume and cover letter.

4. A cover letter format is included to show you all the parts of the letter and what each part contains. Follow the format on the following page for your letter. 
Your Name

Your Address

Date

Name of Person To Whom you are Writing

Company Title or Position

Name of Company

Company's Address

\section{Salutation}

The first paragraph gives the purpose of your letter and states why you sent your resume.

Your qualifications for the position or company go in this second paragraph.

What you want to happen as a result this letter or what method you intend to use to contact the employer go in the third paragraph.

A line expressing your appreciation follows the third paragraph.

\section{Complimentary Closing,}

\section{Your Name}




\section{Cover Letter Tips}

- $\quad$ Always try to address your letter to a specific person who is in charge of hiring for a particular position.

- $\quad$ Never address your letter to the Human Resources Manager or the Human Resources Department.

- Adapt your letter to the situation. Mention the companies accomplishments or make note of other information that you know about the company.

- Avoid using jargon or slang. Use clear and precise language, making use of positive, action verbs.

- $\quad$ Plan your cover letter before writing it.

- Request an interview in the third paragraph.

- Use numbers or figures in the second paragraph, whenever possible, to describe your accomplishments.

- $\quad$ Always check your cover letter for spelling and grammatical errors before mailing it.

- $\quad$ Ask another person to read it and give you their opinion.

- Make a copy of the letter so that you will have a record of what you said to the employer.

- $\quad$ Keep your letter to one page.

- $\quad$ Use a business sized envelope to mail you cover letter.

- Never discuss the reasons you left your previous job. This is something for the interview.

- $\quad$ Never state your expected salary.

- $\quad$ Do not bad mouth former employers.

- Never put conditions on your hire, like travel or hours. These are better discussed in the interview.

- $\quad$ Never mention benefits. 


\section{Cover Letter Checklist}

Use the following checklist to evaluate your cover letter.

_ My complete address

The date

The employer's name

The company's name and address

A Salutation addressed to a specific person

The purpose of the letter

An explanation supporting the purpose

A request for action

A closing

A signature

My complete name

The resume is included

The letter is clear

The letter is brief

The letter is well organized

The letter is friendly

The letter is polite

The letter is factual

The letter is personal

The letter uses $81 / 2$ " x 11" paper

The letter is typewritten

The letter uses correct spelling

The letter uses correct grammar

The uses a business format

The letter uses positive, action verbs 


\section{Sample Cover Letter (Known Contact)}

Jane Smith

222 Mill Road

Sunshine, FL 32091

June 10, 2000

Mr. John Johns, Regional Manager

Southeast Furniture Sales

90 Central Drive

Comfort, FL 32888

Dear Mr. Johns:

This letter is to inquire about the possibility of employment with your company in the sales or retail management departments.

I have a great deal of experience in both sales and management. I am a detail-oriented person and have many times been complimented on my ability to organize difficult situations. I believe I can work with the other employees in your organization and make your company an even greater leader in the furniture industry. I feel I have the energy, the desire, and the ability to make a valuable contribution to your company.

I would appreciate an opportunity to meet with you to discuss our mutual interests. I will phone you on Tuesday of next week to answer any questions you might have and to schedule an interview at that time.

I appreciate your consideration and look forward to meeting you.

Sincerely

Jane Smith 


\section{Sample Cover Letter (Known Contact)}

Fred Cooper

581 Elm Lane

Sunshine, FL 32000

June 22, 2000

Ms. Delores Adams, Manager

High Tech Electronics

4122 Drive

Sunshine, FL 32778

Dear Ms. Adams::

Is High Tech Electronics looking for a knowledgeable and experienced buyer? Because of my experience and training, I am seeking this position in your company.

Through previous employment at Gotham Security, I have gained valuable knowledge of the purchasing field and of the highly competitive vendor market. I am detail-oriented, very organized, and possess good work ethics and analytical skills. I have won several employee excellence awards with my current company for good employee relationships and sales records.

I am enclosing a resume for your review. I will call next week to schedule an interview if you are interested in my experience and training for your company. I can be reached at 813-789-2001.

Thank you for your time and consideration.

Sincerely,

Fred Cooper 


\section{Sample Cover Letter (Unknown Contact)}

Sue Williams

2899 Baker Ave.

Apopka, FL 32667

July 07, 2000

Advertiser

Tampa Tribune

P.O. Box 512

Tampa, F1 32567

Re: Insurance Clerk

Dear Advertiser:

I am responding to your advertisement in the Tampa Tribune on July 03. My resume is enclosed for your review.

I have over five years experience in the insurance business and many hours of specialized training dealing with sales, policy analysis, and accounts receivable. Most recently I worked in a position that gave me the opportunity to work with the manager of an independent insurance agency with emphasis on property and automobile insurance. I am hardworking, energetic and eager to learn.

I believe my background would meet the requirements for your business. I look forward to hearing from you at your earliest convenience. I can be reached at (407) 889-3302. I am available for interviews in the morning hours for the following two weeks.

Thank you for your time and consideration.

Sincerely,

Sue Williams 


\section{References}

Beatty, R.H . (1989). The Perfect Cover Letter. New York: John Wiley \& Sons.

Brennan, L.D., Strand, S., Gruber, E.C. (1994). Resumes for Better Jobs, Sixth Edition. New York: McMillan.

Corwen, L. (1995). Your Resume: Key To A Better Job. New York: Macmillan.

O'Brien, J. (1996). The Complete Job Search Organizer: How to get a Great Job--Fast. Washington, DC: The Kiplinger Washington Editors, Inc.

Shaw, C. and Wolford, N. (1992). The FACT Workbook. Columbus, OH: Ohio State University.

This document is FY349, Part 5 of an 8 part series developed for the Department of Family, Youth and Community Sciences, Cooperative Extension Service, Institute of Food and Agricultural Sciences, University of Florida.

Revised version prepared for electronic publication November 2001 by Elizabeth B. Bolton, professor, community development, Department of Family, Youth and Community Sciences, Extension Cooperative Service, Institute of Food and Agricultural Sciences, University of Florida, Gainesville, 32611-0310.

Original version prepared for publication May 1997 by Elizabeth B. Bolton, professor, community development, Department of Family, Youth and Community Sciences and George O. Hack, assistant in Department of Family, Youth and Community Sciences, Extension Cooperative Service, Institute of Food and Agricultural Sciences, University of Florida, Gainesville, 32611-0310.

The Institute of Food and Agricultural Sciences is an equal opportunity/affirmative action employer authorized to provide research, educational information and other services only to individuals and institutions that function without regard to race, color, sex, age, handicap, or national origin. For information on obtaining other extension publications, contact your county Cooperative Extension Service office.

Florida Cooperative Extension Service/Institute of Food and Agricultural Sciences/University of Florida/Christine Taylor Waddill, Dean 